\title{
KAJIAN STRUKTUR RESISTIVITAS DANGKAL di SEKITAR SUMUR SINDU KECAMATAN JATITUJUH KABUPATEN MAJALENGKA
}

\author{
Bambang Wijatmoko ${ }^{1, a)}$, Budy Santoso ${ }^{1, b)}$, Eddy Supriyana ${ }^{1}$ \\ ${ }^{1}$ Laboratorium Geofisika Lingkungan dan Sumber Daya Alam, Departemen Geofisika FMIPA Unpad \\ Jl. Raya Bandung - Sumedang Km. 21, Jatinangor, Sumedang 45363
}

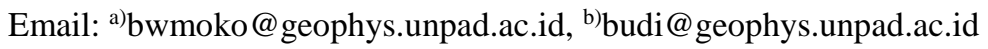

\begin{abstract}
Abstrak
Sumur Sindu merupakan salah satu cagar budaya peninggalan sejarah yang terletak di Desa Sumber Wetan Kecamatan Jati Tujuh Kabupaten Majalengka. Sumur yang dikenal keramat ini sudah digunakan sebagai sumber mata air yang tidak pernah kering. Namun demikian, di sekitar lokasi sumur sering mengalami kekeringan di musim kemarau, bahkan di tempat-tempat tertentu tidak dijumpai sumber air tanah. Hal ini menarik untuk dikaji mengenai bagaiman struktur bawah permukaan di daerah sekitar sumur tersebut. Makalah ini akan membahas tentang struktur resistivitas dangkal yang diperoleh melalui teknik Electrical Resistivity Tomography (ERT) pada tiga lintasan. Hasil pengukuran selanjutnya diolah menggunakan metode inversi 2D sehingga diperoleh suatu penampang yang menggambarkan struktur perlapisan batuan bawah permukaan berdasarkan nilai resistivitasnya. Interpretasi terhadap ketiga penampang menunjukkan bahwa struktur resistivitas daerah penelitian dapat dikelompokkan menjadi lima kategori, yaitu sangat rendah (1-7 ohm.m) berasosiasi dengan akuifer, rendah $(8-17$ ohm.m) berasosiasi dengan lempung pasiran dan lempung, sedang (18-40 ohm.m) berasosiasi dengan pasirlempungan, tinggi (41-90 ohm.m) berasosiasi dengan pasir kerikil, dan kategori sangat tinggi (91$180 \mathrm{ohm} . \mathrm{m}$ ) yang diduga berasosiasi dengan batupasir padat. Pola pelipatan berupa antiklin juga terlihat pada citra penampang tersebut, hal ini menjadi indikasi kemungkinan adanya zonasi akuifer.
\end{abstract}

Kata-kata kunci: struktur resistivitas, sumur sindu, ERT, zonasi akuifer

\begin{abstract}
Sindu well is one of the cultural heritage located in Desa Sumber Wetan Kecamatan Jati Tujuh Kabupaten Majalengka. The well is known sacred and it has been used as a water source that never dry. However, the location around the well droughts in the dry season, and even in certain places the source of groundwater cannot be found. It is interesting to study about how the subsurface structure in the area around the well. This paper will discuss the shallow resistivity structure obtained through Electrical Resistivity Tomography (ERT) on three lines. The result of the measurement will processed using 2D inversion methods to obtain a cross-section that describes the structure of rock layering in subsurface based on resistivity value. Interpretation of the three cross sections showed that the resistivity structure of the study area can be grouped into five categories i.e. very low $(1-7 \mathrm{ohm} . \mathrm{m})$ associated with the aquifer, low (8-17 ohm.m) associated with sandy clay and clay, medium (18-40 ohm.m) associated with sandy clay, high (41-90 ohm.m) associated with gravel, and the very high category (91-180 ohm.m) allegedly associated with solid sandstone. The image of the cross section also described the folding pattern in the form of the anticline which indicate the possibility of aquifer.
\end{abstract}


Keywords: resistivity structure, Sindu well, ERT, aquifer zone.

\section{PENDAHULUAN}

Sumur Sindu merupakan peninggalan sejarah di Desa Sumber Wetan Kecamatan Jatitujuh yang ditetapkan sebagai salah satu cagar budaya Kabupaten Majalengka. Sumber mata air yang dikenal keramat ini tidak pernah kering di waktu kemarau panjang sekalipun. Hal ini berbeda dengan keadaan disekitarnya. Sebagian besar warga, memanfaatkan air tanah permukaan yang diperoleh melalui pengeboran untuk memenuhi keperluan sehari-hari. Namun, di beberapa tempat tidak ditemukan mata air yang memadai walaupun sudah dibor sampai puluhan meter. Disamping itu, banyak sumur yang mengalami kekeringan pada saat musim kemarau. Kondisi seperti ini sering dijumpai di Desa Sumber Kulon yang berjarak sekitar satu kilometer di sebelah selatan Sumur Sindu. Warga desa ini terpaksa harus mengambil air dari kampung yang lain melalui pipanisasi.

Secara topografi, daerah Sumur Sindu dan sekitarnya yang terletak di Majalengka bagian utara, merupakan dataran rendah. Arealnya terutama dimanfaatakan untuk lahan pertanian berupa pesawahan padi dan sebagian untuk perkebunan tebu milik Perhutani sebagai pensuplai Pabrik Gula Jatitujuh. Litologi yang dominan adalah endapan vulkanik dan endapan aluvial yang ditransportasi oleh Sungai Cimanuk [1]. Menurut Soetrisno, S. (1985), hidrogeologi daerah ini merupakan akuifer berproduksi sedang dengan penyebaran luas maupun setempat [2].

Permasalahan fluktuasi air tanah dan penyebaran lapisan akuifer yang tidak merata tersebut menarik untuk dikaji. Kemungkinan hal ini berkaitan dengan keadaan struktur bawah permukaan di daerah sekitar Sumur Sindu. Oleh karena itu, perlu dilakukan pemetaan bawah permukaan menggunakan metode geofisika. Salah satu metode yang sering digunakan untuk tujuan tersebut adalah geolistrik DC. Junizar Kasoep (1998) telah melakukan pendugaan geolistrik untuk mengetahui kondisi bawah permukaan di daerah Tuban [3]. Undang Mardiana dan Cipta Endyana (2014) menggunakan metode geolistrik DC untuk menduga keterdapatan akifer airtanah di Sub-DAS Cisatang Kabupaten Cianjur [4], sedangkan Hasbi Bahri, dkk., telah menggunakan metode ini untuk eksplorasi airtanah di Kabupaten Barru, Sulawesi Selatan [5].

Dalam makalah ini dibahas penerapan metode geolistrik DC untuk menduga struktur resistivitas dangkal di sekitar Sumur Sindu, kecamatan Jatitujuh Kabupaten Majalengka. Penafsiran terhadap struktur resistivitas tersebut dengan didukung oleh data-data yang lain akan memberikan gambaran mengenai perlapisan batuan yang terdapat dibawah permukaan, sehingga dapat dijadikan sebagai pedoman atau petunjuk terkait obyek yang sedang dikaji. Dalam hal ini adalah kondisi dan penyebaran lapisan akuifer di sekitar Sumur Sindu yang mengandung airtanah prospektif.

\section{METODE PENELITIAN}

Pendugaan bawah permukaan yang dilakukan dalam penelitian ini menggunakan kajian geofisika dengan metode geolistrik DC. Prinsip dasar metode geolistrik DC adalah memanfaatkan sifat penjalaran arus listrik yang diinjeksikan kedalam tanah melalui dua buah elektrode kemudian diukur respon beda potensial yang terjadi antara dua buah elektrode yang ditancapkan di permukaan [6]. Dari informasi nilai arus listrik yang diinjeksikan dan besarnya respon beda potensial (tegangan) yang terukur di permukaan, selanjutnya dapat dihitung resistivitas semu medium batuan. Resistivitas batuan merupakan sifat intrinsik bahan yang berkaitan dengan kemampuan menghantarkan arus listrik. Semakin besar nilai resistivitasnya, maka semakin mudah mengalirkan arus listrik.

Pengukuran geolistrik DC dapat dilakukan dengan berbagai cara. Salah satunya adalah tomografi resistivitas 2D atau dikenal dengan istilah teknik pemindaian Electrical Resistivity Tomography (ERT). ERT merupakan cara pengukuran untuk memperoleh informasi mengenai variasi resistivitas secara 2D, yaitu mapping resistivitas dengan variasi spasi elektrode cukup banyak [7]. Teknik pemindaian ERT menghasilkan citra berupa penampang resistivitas yang menggambarkan struktur resistivitas. Metode ERT sudah banyak diterapkan untuk kajian berbagai hal, seperti pendugaan lapisan batubara [8], lapisan akuifer di daerah vulkanik dan sedimen [9], maupun deliniasi cebakan mineral logam [10]. Metode ERT juga dimanfaatkan untuk pemantauan pencemaran air tanah akibat limbah industri [11,12]. 
Dalam penelitian ini, konfigurasi yang digunakan adalah dipol dipol. Dipol pertama merupakan dua buah elektrode untuk menginjeksikan arus listrik (I) sedangkan dipol berikutnya adalah dua elektrode untuk mengukur respon tegangan (V). Masing-masing dipol berjarak a dan pengukurannya dilakukan secara berulang pada jarak na, dengan $\mathrm{n}$ merupakan bilangan bulat $(1,2,3$, dan seterusnya). Semakin besar nilai $\mathrm{n}$, berkorelasi dengan penetrasi arus semakin dalam, sehingga seluruh pengukuran akan membentuk pseudosection [13]. Skema penyusunan elektrode untuk pengukuran tersebut ditunjukkan pada Gambar 1.

Dari setiap pengukuran pada $\mathrm{n}$ dan posisi elektrode tertentu, diperoleh besarnya arus listrik (I) yang diinjeksikan dan nilai respon tegangan $(\mathrm{V})$ yang terukur pada elektrode potensial di permukaan, sehingga dapat dihitung resisitivitas semu untuk datum pengukuran tersebut. Apabila seluruh datum sudah diukur, maka nilai resistivitas semunya dapat ditampilkan dalam bentuk pseudosection. Dengan menggunakan program inversi 2D, pseudosection resistivitas semu tersebut dapat diolah untuk menghasilkan model interpretasi berupa penampang resistivitas 2D. Tingkat kepercayaan model yang didapat ditunjukkan oleh RMS error yang diestimasi berdasarkan korelasi antara pseudosection resistivitas semu hasil pengamatan dan resistivitas semu yang dihitung dari model interpretasi.

Peralatan utama yang digunakan adalah resistivitymeter Naniura tipe NRD 300 HF dilengkapi 41 buah elektrode dan kotak multi switch. Pengukuran dilakukan pada Lintasan 1 berarah Barat-Timur, panjang $360 \mathrm{~m}$ dan merupakan batas dari daerah kering (tidak ada air ketika kemarau) dan daerah basah (mengandung air ketika kemarau). Lintasan 2 berada disebelah Utara, berarah Utara-Selatan, panjang $161 \mathrm{~m}$ dan merepresentasikan daerah yang basah. Lintasan 3 terdapat disebelah Selatan, berarah Utara-Selatan, panjang $360 \mathrm{~m}$ dan sebagai representasi dari daerah kering (Gambar 2).

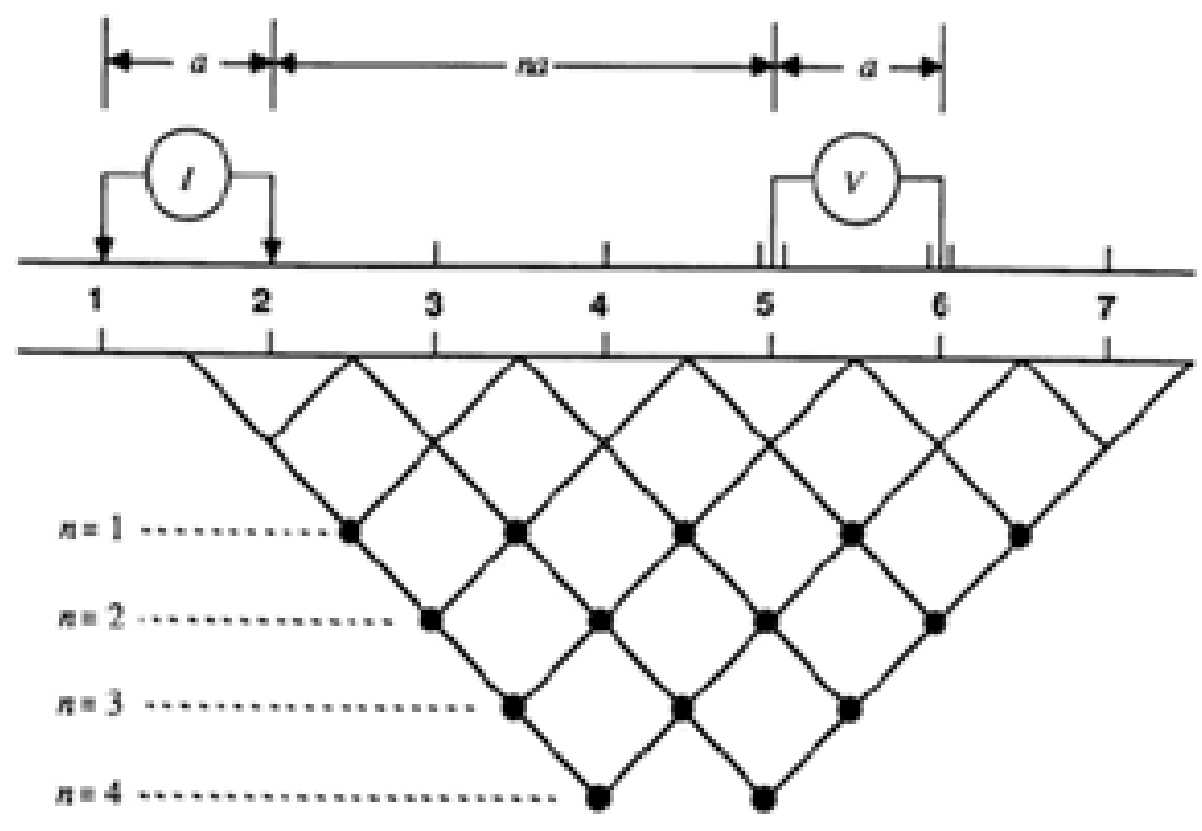

Gambar 1. Skema penyusunan eletrode untuk pengukuran geolistrik secara tomografi 2D menggunakan konfigurasi dipol dipol (Loke, 2004). Dipol pertama merupakan dua buah elektrode untuk meningjeksikan arus listrik I sedangkan dipol kedua merupakan dua buah elektrode potensial untuk mengukur tegangan (V). Masing-masing dipol berjarak a dan pengukuran dilakukan secara berulang pada posisi elektrode tertentu dan jarak na dengan $n$ merupakan bilangan bulat $(1,2$, 3 , danseterusnya). 


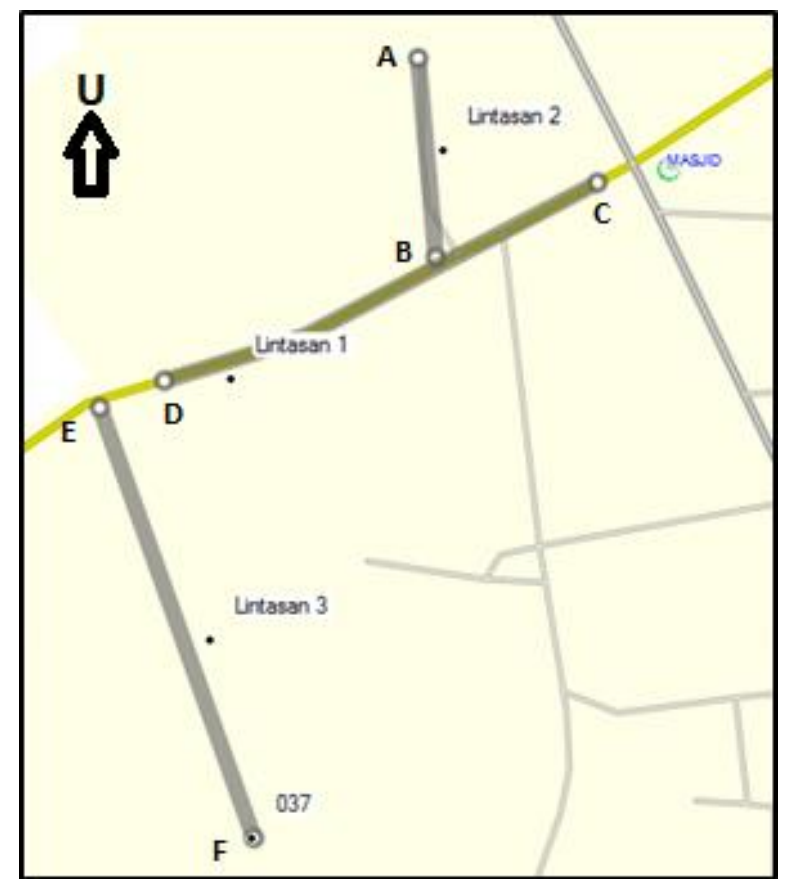

Gambar 2. Peta lintasan pengukuran geolistrik. Lintasan 1 (segmen CD) sepanjang $360 \mathrm{~m}$, merupakan representasi dari batas antara daerah yang kering di sebelah selatan dan daerah basah di sebelah utara. Lintasan 2 (segmen AB) sepanjang $161 \mathrm{~m}$, merupakan representasi dari daerah basah. Lintasan 3 (segmen EF) sepanjang 360 m, merupakan representasi dari daerah yang kering.

\section{HASIL DAN PEMBAHASAN}

Penampang resistivitas hasil pengukuran di ketiga lintasan ditampilkan pada Gambar 3. Penampang ini merupakan citra atau gambaran struktur bawah permukaan di sekitar lintasan pengukuran berdasarkan nilai resistivitas listrik batuan, atau dapat disebut sebagai struktur resistivitasl. Nilai resistivitas yang rendah mengindikasikan lapisan yang konduktif atau mudah mengalirkan arus listrik. Sebaliknya nilai resistivitas yang besar mengindikasikan lapisan yang tidak konduktif, artinya sukar mengalirkan arus listrik. Secara umum, batuan memiliki resistivitas yang tinggi, namun nilainya akan menurun sesuai dengan kandungan air yang ada pada pori batuan tersebut [14].

Kedalaman struktur resistivitas yang diperoleh sangat bergantung pada panjang bentangan pengukuran. Semakin panjang bentangan, maka akan diperoleh struktur resistivitas yang semakin dalam. Pengukuran pada Lintasan 1 dan Lintasan 2 menggunakan 41 buah elektrode dengan spasi 9 $\mathrm{m}$, sehingga panjang bentangannya $360 \mathrm{~m}$. Sedangkan pada Lintasan 2, hanya memungkinkan untuk menggunakan 24 elektrode dengan spasi $7 \mathrm{~m}$, sehingga panjang bentangannya hanya $161 \mathrm{~m}$. Oleh karena itu, terdapat perbedaan kedalaman optimal struktur resistivitas yang diperoleh, yaitu $53 \mathrm{~m}$ untuk Lintasan 1 dan Lintasan 3, serta 30 m untuk Lintasan 2. Kisaran kedalaman sebesar itu, dapat dikategorikan menjadi struktur resistivitas dangkal.

Hasil pengukuran resistivitas pada ketiga lintasan menunjukkan rentang nilai sebesar $(1-180)$ ohm.m. Menurut Reynolds (1998), kisaran nilai resistivitas tersebut berasosiasi dengan sedimen lempung yang mempunyai kadar air maupun campuran yang bervariasi [14]. Hal ini mengindikasikan bahwa keberadaan sedimen cukup tebal, karena sampai kedalaman $53 \mathrm{~m}$, belum dijumpai lapisan batuan alas (basement) yang biasanya berasosiasi dengan batuan beku yang mempunyai resisitivitas diatas ribuan ohm.m. Kemungkinan hal ini berkaitan erat dengan peran daerah aliran Sungai Cimanuk sebagai wahana transportasinya. Sehingga endapan aluvial mendominasi daerah tersebut.

Berdasarkan korelasi dengan data Sumur Ai3 dan Sumur Am5ok yang berada di Lintasan 2, rentang resistivitas hasil pengukuran dapat dikelompokkan menjadi lima kategori seperti ditunjukkan Gambar 3 bagian kiri bawah. Kategori pertama (sangat rendah) adalah rentang resistivitas $(1-7)$ 
ohm.m yang berasosiasi dengan lapisan akuifer. Kategori kedua (rendah) adalah rentang resistivitas ( 8 - 17) ohm.m yang berasosiasi dengan lempungpasiran atau lempung. Kategori ketiga (sedang) adalah rentang resistivitas $(18$ - 40) ohm.m yang berasosiasi dengan pasir lempungan. Kategori keempat (tinggi) adalah rentang resistivtas $(41$ - 90) yang berasosiasi dengan pasirlempungan. Kategori kelima (sangat tinggi) adalah rentang resistivitas (91 - 180) ohm.m yang berasosiasi dengan batupasir padat.

Pada penampang resistivitas Lintasan 1, lapisan akuifer mempunyai kedalaman rata-rata $23 \mathrm{~m}$, muka air tanah rata-rata 6,5 m yakni terdapat pada jarak $(0-360) \mathrm{m}$. Pada jarak $(45-63) \mathrm{m}$, sekitar rumah Pak Kuwu, terdapat pola lipatan berupa antiklin, dimana lapisannya terdiri atas lempungpasiran campur lumpur, lempung, pasirlempungan dan tidak ditemukan adanya akuifer. Pada jarak $(72-99) \mathrm{m}$ terdapat pola lipatan berupa cekungan, pada lapisan ini terdapat akuifer dengan kedalaman $22 \mathrm{~m}$ dan muka air tanah 1,54 m. Akuifer pada lintasan 1 polanya memanjang mulai jarak $(0-360) \mathrm{m}$, muka air tanah akuifer dibatasi oleh lapisan diatasnya yang terdiri atas lempungpasiran, lempung, dan pasirlempungan. Pada jarak $(90$ - 99) m terdapat lempungpasiran yang menyebar vertikal ke bawah sampai kedalaman $17 \mathrm{~m}$. Lempungpasiran tersebut merupakan lapisan semi impermeable yang masih dapat meloloskan air tetapi dengan pergerakan sangat lambat. Dibawah lapisan akuifer dengan kedalaman rata-rata lebih dari $30 \mathrm{~m}$, terdapat pasirlempungan, pasir kerikil, dan pada kedalaman $53 \mathrm{~m}$ diduga terdapat batupasir (padat).

Pada Lintasan 2 terdapat dua sumur bor yaitu pada jarak 101,5 m (Sumur Ai3) dan 119 m (Sumur AM5ok). Selain itu, pada jarak lintasan $56 \mathrm{~m}$ ke arah Timur (kurang lebih $20 \mathrm{~m}$ ) terdapat sumur bor MCK. Hasil pengukuran geolistrik yang telah dikorelasikan dengan Sumur Ai3 dan Sumur AM5ok, menunjukkan bahwa di kedalaman $11 \mathrm{~m}$ diduga terdapat lapisan akuifer pada jarak $(49-119) \mathrm{m}$, dengan muka air tanah 1,2 m. Pada lapisan dibawah akuifer terdapat perselingan lempungpasiran dengan lempung. Akuifer yang terdapat pada Lintasan 2 mempunyai perbedaan, yaitu muka air tanahnya sangat dangkal, yaitu diperkirakan dengan kedalaman kurang dari $1 \mathrm{~m}$.

Ketika musim kemarau muka air tanah pada Sumur Ai3 dan AM5ok turun pada kedalaman (3 - 5) $\mathrm{m}$ dari permukaan tanah. Kedalaman sumur bor tersebut kurang lebih $6 \mathrm{~m}$, sehingga sumur bor tersebut masih mengandung air ketika musim kemarau. Air yang terdapat di reservoir tersebut kemungkinan akan mengalir dan terakumulasi pada jarak $115 \mathrm{~m}$. Jenis akuifer pada lintasan ini yaitu unconfined aquifer. Unconfined aquifer yaitu akuifer jenuh air (saturated) dimana lapisan pembatasnya (aquitard) hanya pada bagian bawahnya dan tidak ada pembatas aquitard di lapisan atasnya, batas di lapisan atas berupa muka air tanah [15]. Batuan pembatas yang berfungsi sebagai penyekat pada lintasan ini diduga merupakan lempungpasiran atau lempung.

Penampang Lintasan 3 mempunyai pola perlapisan berupa lipatan, dengan bentuk cekungan pada bagian tengah lintasan pada jarak (117 - 234) $\mathrm{m}$ serta pada bagian tepi lintasan pada jarak $(0-54) \mathrm{m}$ dan jarak (288 - 360) $\mathrm{m}$. Air tanah akuifer akan terkonsolidasi pada lapisan impermeable (cekungan) yang diduga sebagai lempung. Pada lapisan dibawahnya dengan pola yang sama (cekungan) terdapat beberapa perlapisan batuan, yaitu pasir lempungan, pasir kerikil, dan batupasir (padat). Jenis batuan yang terdapat pada lapisan pembatas atas akuifer, yaitu lempung, lempungpasiran dan pasir lempungan. Keberadaan lapisan akuifer relatif lebih dalam dibandingkan di posisi Lintasan 2. Ketika musim kemarau semua sumur warga mengalami kekeringan, karena muka air tanah menurun dan mengalir mengisi cekungan yang lebih dalam di sekitar jarak $180 \mathrm{~m}$. Kedalaman rata-rata sumur bor di sepanjang lintasan ini adalah $9 \mathrm{~m}$, sementara penurunan mauka air tanah bisa mencapai lebih dari $9 \mathrm{~m}$. Akibatnya semua sumur bor menjadi kering. 


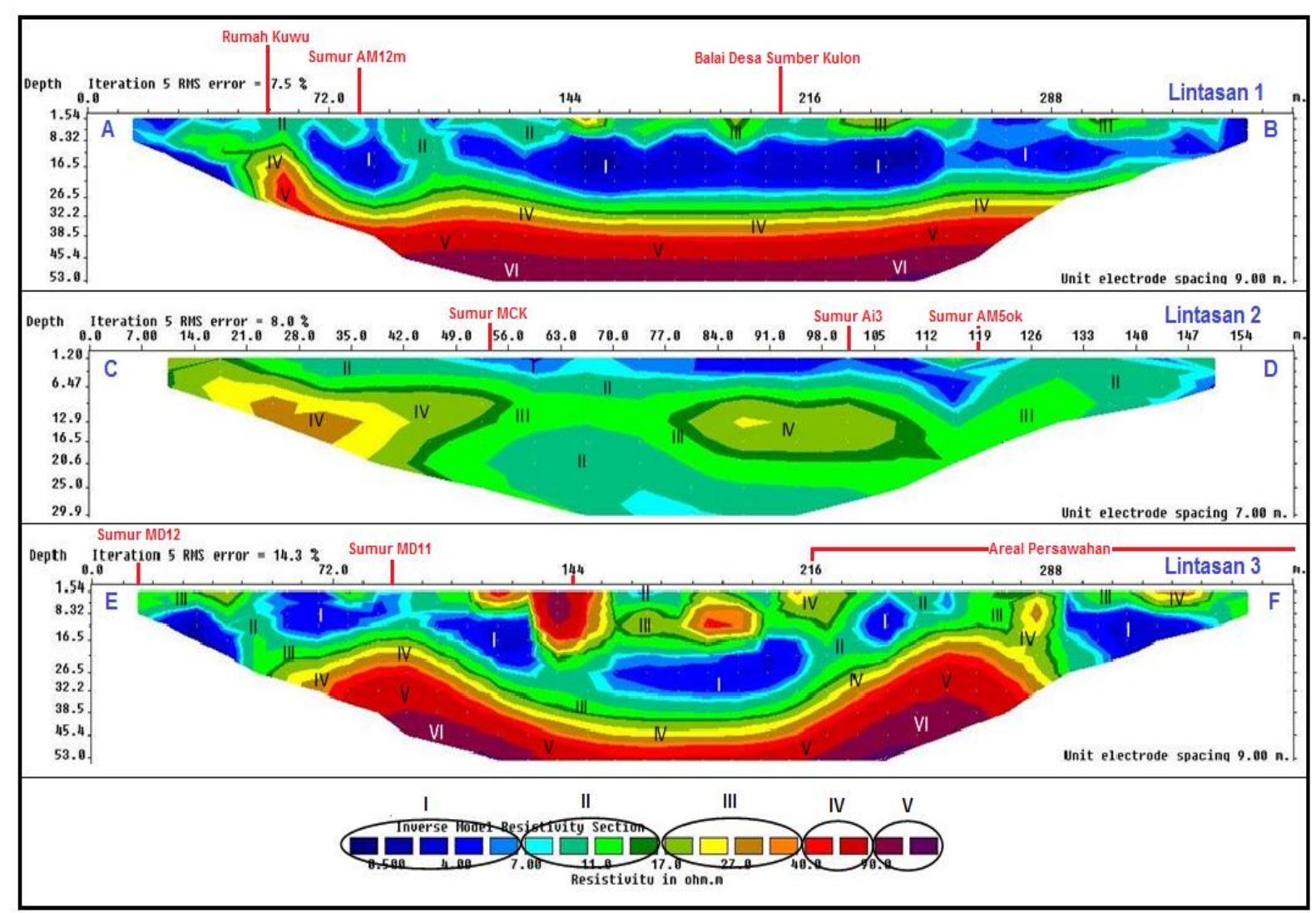

Gambar 3. Penampang resistivitas hasil pengukuran ketiga lintasan di Desa Sumber Kulon, yaitu Lintasan 1 (gambar paling atas), Lintasan 2 (gambar kedua), dan Lintasan 3 (gambar ketiga). Pada gambar bawah, ditunjukkan pengelompokan nilai resistivitas yang berkaitan dengan penafsiran litologi.

Indikasi menarik lain yang ditunjukkan oleh struktur resisitivitas dangkal di sekitar Sumur Sindu adalah terjadinya pola lipatan perlapisan batuan bawah permukaan. Hal ini berbeda dengan kenampakan morfologi permukaan yang berupa dataran. Pola lipatan yang dominan dalam arah relatif Utara - Selatan jelas terlihat pada Lintasan 3, sedangkan dalam arah Barat - Timur, perlapisannya relatif lebih mendatar, walaupun terindikasi juga semacam antiklin seperti terlihat pada Lintasan 1, yaitu sekitar rumah Pak Kuwu. Pola lipatan berkaitan dengan bentuk struktur tinggian dan rendahan yang sangat berpengaruh terhadap distribusi lapisan akuifer. Air tanah cenderung terakumulasi pada posisi rendahan yang membentuk semacam cekungan. Semakin banyak air terakumulasi, maka semakin dangkal muka air tanahnya. Sebaliknya di posisi tinggian, keberadaan air tanah akan menipis, bahkan tidak ada.

Pola lipatan dan jenis litologi penyusun lapisan batuan diduga merupakan faktor penting yang menjadi penyebab terjadinya sebaran akuifer dan fluktuasi muka air tanah yang tidak merata. Daerah kering kemungkinan berada di posisi-posisi tinggian, sedangkan daerah basah berada di rendahan. Pada saat musim hujan, air tanah akan mengisi reservoir sampai ke daerah tinggian, namun ketika musim kemarau akan surut dan hanya terakumulasi di rendahan saja. Sumur-sumur bor di daerah tinggian akan menembus lapisan akuifer yang tipis dan cepat surut, atau bahkan kering di musim kemarau, sedangkan di rendahan akan berkaitan dengan lapisan akuifer yang tebal dan masih ada cadangan airnya hingga musim kemarau. Informasi pemetaan bawah permukaan ini sangat 
diperlukan untuk menentukan posisi-posisi pengeboran yang tepat dalam melakukan eksplorasi sumber air tanah.

\section{SIMPULAN}

Struktur resistivitas dangkal di sekitar Sumur Sindu menunjukkan bahwa sampai kedalaman sekitar 53 meter, diperoleh nilai resisitivitas $(1-180)$ ohm.m yang ditafsirkan sebagai endapan sedimen. Akuifer jenuh air diindikasikan oleh nilai resistivitas $(1-7)$ ohm.m., sedangkan nilai resistivitas $(8-180)$ ohm.m., berasosiasi dengan lempung, pasir dan padatan batupasir. Pola lipatan membentuk tinggian dan rendahan yang dominan dalam arah Utara-Selatan berpengaruh terhadap penyebaran akuifer yang tidak merata dan terjadinya fluktuasi muka air tanah pada saat musim hujan dan musim kemarau.

\section{UCAPAN TERIMAKASIH}

Terimakasih kepada pihak DRPM Universtas Padjadjaran yang telah memberikan dana penelitian serta Jajaran Muspida Majalengka, Muspika Jatitujuh dan Desa Sumber Kulon yang telah memberi ijin pelaksanaan penelitian.

\section{DAFTAR ACUAN}

[1] Djuri, Peta Geologi Skala 1:100000 Lembar Cirebon, Direktorat Geologi (1973).

[2] Soetrisno, S., Peta Hidrogeologi Indonesia Skala 1:250000 Lembar II Cirebon, Direktorat Geologi Tata Lingkungan (1985).

[3] Junizar Kasoep, Pendugaan Geolistrik Di Cekungan Sugihan-Suwalan Kecamatan Jenu dan Merak Urak Kabupaten Tuban Provinsi Jawa Timur, Buletin Geologi Tata Lingkungan, Nomer 24, September (1998), pp. 40-52.

[4] Undang Mardiana dan Cipta Endyana, Pendugaan Keterdapatan Akifer Airtanah Dengan Metode Geolistrik Konfigurasi Schlumberger Di Sub DAS Cisatang Kabupaten Cianjur, Bulletin of Scientific Contribution, Volume 12, Nomer 2, Agustus (2014), pp. 69-77

[5] Hasbi Bahri, Jamal Rauh Husain, dan Firdaus, Pendugaan Airtanah Dengan Metode Geolistrik Tahanan Jenis Di Desa Tellumpanua Kecamatan Tanete Rilau Kabupaten Barru, Sulawesi Selatan, Jurnal Geomine, Volume 03, Desember (2015), pp. 165-169.

[6] Telford, W.M., Geldart, L.P. \& Sheriff, R.E., Applied Geophysics, New York, Cambridge, (1990), p. 522.

[7] Grandis, Lecture-note : Geolekstromagnetisme, http://www.geoph.itb.ac.id, (2006).

[8] Bambang Wijatmoko, Budy S., Asep Harja, dan Marlan, Pengukuran Resistivitas Pada Singkapan Batubara, PIT HAGI Ke 34, Yogyakarta, (2009).Mempertegas Posisi Polutan dan Air Bersih di Pusat Industri Kulit Garut, Dharmakarya, ISSN 2302-8955 Volume 1 No. 1 Bulan Mei, (2012), pp. 41-48.

[9] Asep Harja dan Bambang Wijatmoko, Interpretasi Pendugaan Air Tanah Pada Daerah Vulkanik dan Sedimen, Seminar Nasional Fisika Unnes, Semarang, (2011).

[10] Bambang Wijatmoko, Eddy Supriyana, dan Asep Harja, Aplikasi Metode TDIP (Time Domain Induced Polarization) Untuk Pendugaan Cebakan Mineral Logam Di Daerah Kampar Propinsi Riau, Seminar Nasional Sains dan Teknologi IV, Unila Lampung, (2011).

[11] Bambang Wijatmoko dan Hariadi, Studi Pola Sebaran Dan Kedalaman Polusi Air Tanah Berdasarkan Nilai Resistivitas Di Sekitar Saluran Pembuangan Air Limbah Industri Rancaekek Kabupaten Bandung, Bionatura, ISSN 1411 - 0903 Volume 10 No. 1 Bulan Maret, (2008), pp. $58-67$. 
[12] Bambang Wijatmoko, Eleonora Agustine, dan Kusnahadi Susanto, Pemanfaatan Metode Electrical Resistivity Tomography (ERT) untuk

[13] Loke, M.H., Tutorial : 2D and 3D Electrical Imaging Surveys, http://www.geoelectrical.com, (2004).

[14] Reynolds, J.M., An Introduction to Applied and Environmental Geophysics, New York, John Willey and Sons, (1998), p. 422.

[15] Kodoatie, RJ., Pengantar Hidrogeologi, Andi Offset, Yoyakarta ((1996), p. 82. 